\title{
Tinjauan Sosiologi Sastra dalam Novel Hafalan Shalat Delisa Karya Tere Liye dan Relevansinya terhadap Pembelajaran Sastra di SMA
}

\author{
Rita Nilawijaya \\ (corresponding author) \\ Universitas Baturaja, Indonesia \\ Email: nilawijaya.rita@gmail.com \\ Awalludin \\ Universitas Baturaja, Indonesia \\ Email: awalludinawri@gmail.com
}

\begin{abstract}
APA Citation: Nilawijaya, R. \& Awalludin, A. (2021). Tinjauan sosiologi sastra dalam novel Hafalan Shalat Delisa karya Tere Liye dan relevansinya terhadap pembelajaran sastra di SMA. Silampari Bisa: Jurnal Penelitian Pendidikan Bahasa Indonesia, Daerah, dan Asing, 4(1), 13-24. https://doi.org/10.31540/silamparibisa.v4i1.1212
\end{abstract}

\begin{abstract}
Abstrak
Tujuan penelitian ini adalah untuk mendeskripsikan struktur pembangun novel, aspek moral dalam novel Hafalan Shalat Delisa karya Tere Liye, dan relevansinya terhadap pembelajaran sastra di SMA. Metode penelitian yang digunakan adalah metode deskriptif kualitatif. Objek penelitian ini adalah aspek moral. Sumber data dalam penelitian ini adalah novel Hafalan Shalat Delisa karya Tere Liye. Teknik pengumpulan data menggunakan teknik pustaka, simak, catat, dan wawancara. Teknik analisis data menggunakan teknik dialektika. Hasil penelitian menunjukkan bahwa (1) analisis struktural menghasilkan tema novel ini adalah pantang menyerah, sabar, dan tabah. Alur yang digunakan adalah alur maju (progresif). Tokoh utama bernama Delisa dan tokoh tambahan yaitu Ummi Salamah, Kak Fatimah, Kak Aisyah, Kak Zahra, Abi Usman, Koh Acan, Ustadz Rahman, Ibu Guru Nur, Sersan Ahmed, Prajurit Smith/Salam, Suster Shopi, Tiur, Umam, dan Kak Ubai. Latar tempat dalam novel ini berlokasi di Lhok Nga, kapal induk, dan rumah sakit. Latar waktunya terjadi antara tahun 2004 sampai dengan 2005. Latar sosial meliputi kebiasaan hidup, tradisi, dan keyakinan dalam beragama; (2) aspek moral dalam novel Hafalan Shalat Delisa meliputi kejujuran, nilai-nilai otentik, tanggung jawab, kemandirian, serta moral realistik dan kritis. Kemudian, (3) hasil penelitian ini memiliki relevansi terhadap pembelajaran sastra di SMA yang ditunjukkan dengan adanya materi tentang nilai moral dalam novel sebagai bagian dari pendidikan karakter yang harus dipelajari oleh siswa.
\end{abstract}

Kata kunci: tinjauan sosiologi sastra, novel, pembelajaran sastra

\section{Overview of the Sociology of Literature in the Hafalan Shalat Delisa Novel by Tere Liye and its Relevance to Literary Learning in High School}

\begin{abstract}
The purpose of this study was to describe the novel building structure, the moral aspects of Tere Liye's Hafalan Shalat Delisa novel, and its relevance to literary learning in high school. The research method used is descriptive qualitative method. The object of this research is the moral aspect. The data source in this study is the novel Hafalan Shalat Delisa by Tere
\end{abstract}


Rita Nilawijaya, Awalludin

Tinjauan Sosiologi Sastra dalam Novel Hafalan Shalat Delisa Karya Tere Liye dan Relevansinya terhadap

Pembelajaran Sastra di SMA

Liye. The technique of collecting data uses library techniques, listening, taking notes, and interviews. Data analysis techniques using dialectical techniques. The results showed that (1) structural analysis resulted in the theme of this novel being unyielding, patient, and steadfast. The flow used is a progressive path. The main character is named Delisa and additional figures are Ummi Salamah, Kak Fatimah, Kak Aisyah, Kak Zahra, Abi Usman, Koh Acan, Ustadz Rahman, Ibu Guru Nur, Sersan Ahmed, Prajurit Smith/Salam, Suster Shopi, Tiur, Umam, and Kak Ubai. The setting in this novel is located in Lhok Nga, the aircraft carrier, and the hospital. The time frame is between 2004 and 2005. The social background includes life habits, traditions, and beliefs in religion; (2) moral aspects in the novel Hafalan Shalat Delisa include honesty, authentic values, responsibility, independence, and realistic and critical morals. Then, (3) the results of this study have relevance to literature learning in high school which is indicated by the existence of material about moral values in novels as part of character education that must be learned by students.

Keywords: sociology review of literature, novel, literary learning

\section{A. Pendahuluan}

Karya sastra merupakan sebuah struktur yang kompleks dan isinya berusaha menceritakan peristiwa yang sebenarnya di masyarakat (Noermanzah, 2017:28). Untuk memahaminya perlu adanya analisis terhadap bagian-bagian atau unsurunsurnya. Sesungguhnya, analisis itu merupakan salah satu sarana penafsiran atau interpretasi (Pradopo, 2008:93). Aspek yang dikaji dalam penelitian ini adalah sosiologi sastra. Sosiologi sastra adalah pemahaman terhadap karya sastra dengan mempertimbangkan aspek-aspek kemasyarakatannya (Ratna, 2010:3). Sosiologi sastra diterapkan dalam penelitian ini dengan tujuan untuk meningkatkan pemahaman karya sastra dalam kaitannya dengan kehidupan masyarakat sehari-hari, menjelaskan bahwa rekaan tidak berlawanan dengan kenyataan dalam hal karya sastra yang dikonstruksikan secara imajinatif, akan tetapi struktur empirisnya dan karya sastra bukan hanya semata-mata merupakan wujud gejala individual, tetapi merupakan gejala sosial (Nilawijaya \& Inawati, 2020:23). Sehubungan denga hal tesebut, Awalludin \& Anam (2019) menyatakan bahwa kegiatan sastra itu tidak bisa lepas dari unsur masyarakat melalui intuisi sosial dengan menggunakan medium bahasa.

Berkaitan dengan sosiologi sastra, Ratna (2010:18) menjelaskan bahwa sosiologi sastra itu menggabungkan dua disiplin yang berbeda yaitu sosiologi dan sastra. Dalam sosiologi sastra yang mendominasi jelas teori-teori yang berkaitan dengan sastra, sedangkan teori yang berkaitan dengan sosiologi berfungsi sebagai komplementer. Teori sosiologi yang dapat menopang analisis sosiologis adalah teori-teori yang dapat menjelaskan hakikat fakta-fakta sosial, karya sastra sebagai sistem komunikasi khususnya dalam kaitannya dengan aspek-aspek ekstrinsik. Selain itu, dalam penelitian ini juga dianalisis tentang nilai moral yang terdapat dalam novel tersebut.

Bentuk karya sastra yang menjadi objek kajian dalam penelitian ini adalah novel. Novel merupakan sebuah struktur organisasi dan pemasalahan kehidupan yang kompleks, unik, dan mengungkapkan segala sesuatu secara tidak langung (Sulaeman dkk., 2020:611). Tujuan utama analisis kesastraan, fiksi, puisi, ataupun yang lain adalah untuk memahami secara lebih baik karya sastra yang 
Rita Nilawijaya, Awalludin

Tinjauan Sosiologi Sastra dalam Novel Hafalan Shalat Delisa Karya Tere Liye dan Relevansinya terhadap Pembelajaran Sastra di SMA

bersangkutan. Nurgiyantoro (2012:5) mendefinisikan novel sebagai salah satu dari karya fiksi yang menawarkan sebuah dunia, dunia tersebut berisi model kehidupan yang diidealkan, dunia yang imajinatif, yang dibangun melalui berbagai unsur intrinsiknya. Penelitian terhadap karya sastra penting dilakukan untuk mengungkap berbagai pesan di dalamnya. Aspek moral merupakan bentuk pesan dalam novel yang dapat dikaji menggunakan pendekatan sosiologi sastra. Novel Hafalan Shalat Delisa merupakan novel karya Tere Liye yang menampilkan bentuk aspek moral yang dapat direlevansikan dan diimplementasikan dalam pembelajaran sastra di SMA.

Kajian novel dapat dilihat dari gaya bahasa, pengarang, nilai moral, dan nilai sosial yang terkandung dalam novel tersebut yang dapat diterapkan dalam kehidupan sehari-hari. Penanaman nilai moral sangat dibutuhkan bagi pendidikan karena nilai moral membentuk kepribadian siswa dalam bertindak di lingkungan sosial. Nilai moral diartikan sebagai standar terhadap sesuatu itu baik atau tidak yang menjadi pegangan bagi seseorang dalam mengatur tingkah lakunya (Sukma \& Hafrison, 2020; Liliweri, 2014:70). Nilai moral dikategorikan menjadi nilai moral agama, nilai moral kepribadian, dan nilai moral sosial (Soeparwoto, 2004:60). Selain pendapat tersebut, nilai moral dikategorikan menjadi etika wahyu, etika peraturan, dan etika situasi (Suseno dalam Nilawijaya \& Inawati, 2020:63).

Aspek moral dalam karya sastra/fiksi biasanya mencerminkan suatu pandangan hidup dari diri pengarang, pandangan pengarang tentang nilai-nilai pengarang yang bersangkutan, pandangan tentang nilai dari kebenaran, dan hal tersebut merupakan pesan yang hendak disampaikan oleh seorang pengarang (Nurgiyantoro, 2012:430). Secara etimologis, moral berasal dari kata latin "mos"yang artinya tata cara, adat istiadat atau kebiasaan, sedangkan jamaknya adalah "mores". Dalam arti adat istiadat atau kebijaksanaan, moral mempunyai arti yang sama dengan kata yunani "ethos" yang menurunkan kata "etika". Suseno dalam Nilawijaya \& Inawati (2020:63) mengklasifikasi aspek moral ke dalam lima bentuk yaitu: moral kejujuran, moral nilai-nilai otentik, moral tanggung jawab, moral kemandirian, serta moral realistik dan kritis. Sehubungan dengan uraian tersebut, Sufanti (2010:22) dan Satinem dkk. (2020) berpendapat bahwa ada beberapa manfaat membaca karya sastra sebagai bagian dari apresiasi karya sastra, yaitu meningkatkan wawasan siswa, memperhalus budi pekerti, meningkatkan pengetahuan bahasanya, dan meningkatkan kemampuan berbahasa.

Berdasarkan permasalah tersebut, peneliti tertarik untuk mendeskripsikan hasil tinjauan sosiologi sastra dalam novel Hafalan Shalat Delisa karya Tere Liye dan relevansinya terhadap pembelajaran sastra di SMA sehingga diharapkan dari tinjauan sosiologi mampu memnjelaskan juga nilai-nilai moral yang ada dalam novel tersebut sebagai materi ajar yang bisa digunakan para guru bahasa Indonesia dalam pembelajaran novel di SMA. Sampai saat ini, novel Hafalan Shalat Delisa karya Tere Liye baru diteliti sebatas nilai-nilai pendidikan akhlak oleh Zulaicha (2009), diksi dan kalimatnya dalam novel tersebut oleh Prastica \& Wulandari (2020), dan Wanispa \& Hidajati (2019) tentang nilai pendidikan karakter yang ada dalam novel. 
Rita Nilawijaya, Awalludin

Tinjauan Sosiologi Sastra dalam Novel Hafalan Shalat Delisa Karya Tere Liye dan Relevansinya terhadap Pembelajaran Sastra di SMA

\section{B. Metodologi Penelitian}

Metode yang digunakan dalam penelitian ini adalah metode deskriptif kualitatif. Dengan strategi studi terpancang (embedded research). Dalam penelitian ini diterapkan permasalahan yang meliputi latar sosio-historis pengarang novel, struktur pembangun novel, aspek moral, dan implementasi hasil penelitian sebagai bahan ajar sastra di SMA. Selanjutnya, penerapan studi kasus (case study) dalam penelitian ini adalah dengan memfokuskan hasil penelitian sebagai bahan ajar sastra pada jenjang SMA. Objek penelitian ini adalah aspek moral dalam novel Hafalan Shalat Delisa karya Tere Liye yang dikaji menggunakan pendekatan sosiologi sastra. Sumber data primer penelitian ini yaitu novel Hafalan Shalat Delisakarya Tere Liye. Sumber data sekunder dalam penelitian ini berupa buku referensi dan artikel yang relevan. Teknik pengumpulan data yang digunakan dalam penelitian ini menggunakan teknik pustaka dan teknik catat.

Teknik analisis data dalam penelitian ini menggunakan teknik dialektik. Langkah teknik dialektik yaitu dengan cara mendeskripsikan fakta cerita yang ada dalam novel Hafalan Shalat Delisa karya Tere Liye. Setelah ditemukan fakta cerita, kemudian dianalisis berdasarkan teori strukturalisme Todorov dengan menganalisis aspek atau unsur intrinsik novel berupa sintaksis alur dan pengaluran dan analisis semantik tokoh dan latar.

\section{Hasil Penelitian dan Pembahasan}

1. Hasil Penelitian

a. Analisis Struktural dalam Novel Hafalan Shalat Delisa karya Tere Liye 1) Tema

Tema merupakan aspek dalam cerita yang sejajar dengan makna atau sesuatu yang menjadikan suatu pengalaman begitu diingat dan adanya banyak cerita yang menggambarkan dan menelaah kejadian atau emosi yang dialami oleh manusia seperti cinta, derita, dan rasa takut. Tema dalam novel Hafalan Shalat Delisa karya Tere Liye adalah perilaku pantang menyerah, kerja keras, dan sabar dalam menjalani kehidupan.

\section{2) Alur}

Alur yang digunakan dalam novel Hafalan Shalat Delisa karya Tere Liye yaitu alur maju/progressive. Hal tersebut dapat dilihat pada kutipan berikut.

\footnotetext{
Itulah! Tanpa Delisa sadari, itulah shalat pertamanya yang akan sempurna. Itulah shalat pertamanya yang lengkap. Utuh. Tak lupa satu bacaan-pun. Tak lalai satu gerakan-pun. (Hafalan Shalat Delisa, 2008:259) Kalung itu ternyata bukan tersangkut di dedahanan. Tidak juga tersangkut di dedaunan. Tetapi kalung tersangkut di tangan. Tangan tang sudah menjadi kerangka. Sempurna kerangka manusia. Putih. Tulangbelulang. Utuh. Bersandarkan semak belukar tersebut.

Delisa mendesis lemah, lantas detik berikutnya, jatuh terjerembab ke dalam sejuknya air sungai.

Delisa buncah oleh sejuta perasaan.

“Ummi....". (Liye, 2008:265).
} 
Rita Nilawijaya, Awalludin

Tinjauan Sosiologi Sastra dalam Novel Hafalan Shalat Delisa Karya Tere Liye dan Relevansinya terhadap Pembelajaran Sastra di SMA

Berdasarkan kutipan tersebut, dapat dijelaskan bahwa Delisa berhasil menghafal bacaan salatnya untuk pertama kali, bahkan mempraktikkannya secara lengkap, utuh, dan tanpa terbolak-balik ketika ia sedang salat. Selain itu, keberadaan Ummi Delisa yang masih menjadi teka-teki juga dimunculkan dalam cerita. Diceritakan bahwa Ummi Salamah sudah menjadi mayat dengan keadaan hanya tulang-belulang dan membawa kalung yang pernah Ummi janjikan sebagai hadiah untuk Delisa atas keberhasilannya dalam menghafalkan bacaan salat.

\section{3) Karakter/Tokoh}

Penokohan merupakan penggunaan istilah "karakter" (character) sendiri dalam berbagai literatur bahasa Inggris menyarankan pada dua pengertian yang berbeda, yaitu sebagai tokoh-tokoh cerita yang ditampilkan, dan sebagai sikap, ketertarikan, keinginan, emosi, dan prinsip moral yang dimiliki oleh tokoh-tokoh tersebut. Adapun tokoh utama dalam novel Hafalan Shalat Delisa karya Tere Liye adalah Delisa, sedangkan tokoh tambahan seperti: Ummi Salamah, Kak Fatimah, Kak Aisyah, Kak Zahra, Abi Usman, Ustadz Rahman, Ibu Guru Nur, Koh Acan, Tiur, Umam, Sersan Ahmed, Prajurit Smith/ salam, Suster Shopi, dan Kak Ubai.

\section{4) Latar/Setting}

Latar/setting diartikan sebagai lingkungan yang melingkupi sebuah peristiwa dalam cerita, semesta yang berinteraksi dengan peristiwa-peristiwa yang sedang berlangsung. Latar dalam novel Hafalan Shalat Delisa karya Tere Liye dibagi menjadi tiga, yaitu: a) latar tempat yaitu Kota Lhok Nga dan kapal induk; b) latar waktu yaitu terjadi antara tahun 2004-2005; dan c) latar sosial yaitu kebiasaan hidup, tradisi, dan keyakinan dalam beragama.

\section{b. Aspek Moral dalam Novel Hafalan Shalat Delisa Karya Tere Liye}

Analisis aspek moral dalam novel Hafalan Shalat Delisa karya Tere Liye dikaji menggunakan pendekatan sosiologi sastra. Aspek tersebut diklasifikasikan menjadi 5 macam, yaitu:

1) Kejujuran

Kejujuran adalah keselarasan kata hati dengan kata yang diucapkan. Orang yang jujur adalah orang yang bersikap apa adanya tanpa menyembunyikan maksud tertentu, mengakui segala sesuatu yang terjadi sesuai dengan realitas yang ada. Aspek moral kejujuran dalam novel Hafalan Shalat Delisa karya Tere Liye dapat dilihat dari kutipan berikut.

\footnotetext{
"A-b-i...." Delia berkata lemah. Tersendat. la ingin menangis lagi. Abi menoleh, menghentikan ayunannya. Menatap wajah bungsunya yang begitu dekat dari mukanya.

"Abi.... A-b-i.... D-e-l-i-s-a cinta Abi karena Allah!"
}

Kalimat itu meluncur saja dari mulut Delisa. Meluncur dari hati Delisa tanpa tertahankan. Tercipta tanpa pengharapan imbalan sebatang cokelat. Mengalir dari kemilau hati yang tiada tara. Kalimat itu sebenarnya lemah, disertai sedu-sedan pula, tetapi cukup sudah untuk menghancurkan tembok hati membeku terbesar yang pernah ada. 
Rita Nilawijaya, Awalludin

Tinjauan Sosiologi Sastra dalam Novel Hafalan Shalat Delisa Karya Tere Liye dan Relevansinya terhadap Pembelajaran Sastra di SMA

Abi tergagap. Ya Allah, gadis kecilnya mengatakan kalimat itu. Abi seketika tergugu diam. Bungsunya baru saja mengatakan kalimat indah itu. Kalimat yang diceritakan Ummi dulu. Kalimat yang melelehkan semuanya. Gemetar Abi meraih tubuh Delisa. Menatap mata hijau teduh itu. Menatap Delisa yang memamerkan giginya yang tinggal dua. Abi gentar sekali (Liye, 2008:195).

Aspek moral kejujuran yang terdapat dalam kutipan di atas terbukti pada perkataan dari Delisa yaitu cinta Abi karena Allah Swt. Perkataan tersebut tulus dari seorang Delisa yang masih berusia anak-anak. Kata-kata yang keluar dari Delisa yang masih polos merupakan kata-kata yang tulus dari hatinya.

\section{2) Nilai-Nilai Otentik}

Nilai-nilai otentik dalam novel ini berkaitan dengan moral yang menunjukkan keaslian dari diri sendiri sebagai manusia dengan kepribadian yang ia miliki. Nilai-nilai ini menuntun kita menjadi pribadi yang apa adanya dan teguh terhadap pendirian. Aspek moral nilai-nilai otentik dalam novel Hafalan Shalat Delisa karya Tere Liye dapat dilihat pada kutipan berikut.

\footnotetext{
"Tidaklah .... Kalau untuk hadiah hafalan shalat ini, Ummi Salamah bayar separuh saja, haiya!"

"Buat kamu, kan.... Ah iya nama kamu Delisa, kan? Anak yang manis-" Koh Acan mengusap-usap kerudung Delisa. Delisa tersenyum selucu mungkin. Memasang wajah terbaiknya. Semoga begitu malah gratis.

"Janganlah Koh. Saya jadi tidak enak hati... Dulu waktu Fatimah beli Koh Acan juga hanya mau dibayar separuh, waktu Zahra dan Aisyah beli juga... Kali ini biarlah Delisa bayar penuh..." Ummi mengeluarkan dompet dari tas. Menggambil uang seharga kalung tersebut.

"Nggak... Haiya, saya nggak mungkinlah pasang harga mahal kalau buat hafalan bacaan shalat! Nggak mungkinlah...."

"Kata Abi Usman Dulu, shalat itu kan untuk amm-mar mak-ruf na-khi mhung-kar -" Koh Acan kesulitan mengeja ujung kalimatnya.

"Saya senang sekali anak-anak kecil belajar shalat.... Itu berarti Lhok Nga akan jadi lebih baik, kan.... Apalagi anak-anak Abi Usman dan Ummi Salamah sudah seperti anak saya sendiri ini..." Koh Acan menggeleng tegas menatap. Menggoyanggiyangkan tangannya dengan sopan. (Liye, 2008:20-21).
}

Kutipan tersebut menunjukkan aspek moral nilai-nilai otentik yang dimiliki oleh Koh Acan yang memegang teguh pendiriannya. Kebaikan yang diberikan oleh Koh Acan tersebut tidak dibuat-buat dalam arti tulus dari pribadinya dan bukan hanya mencari simpati semata. Keaslian dari seorang Koh Acan yaitu sebagai bentuk apresiasi Koh Acan terhadap anak-anak yang mau belajar beribadah dengan sungguh-sungguh.

\section{3) Tanggung Jawab}

Tanggung jawab menuntut kesadaran individu dalam berkewajiban dan menangani permasalahan yang dihadapi. Aspek tanggung jawab dalam novel Hafalan Shalat Delisa karya Tere Liye dapat dilihat dari kutipan berikut. 
Rita Nilawijaya, Awalludin

Tinjauan Sosiologi Sastra dalam Novel Hafalan Shalat Delisa Karya Tere Liye dan Relevansinya terhadap Pembelajaran Sastra di SMA

Bagi abi Usman. Kehilangan ini tidaklah sederhana seperti kehilangan Delisa.

Delisa cukup menjadi Delisa saja. Tetapi Abi terpaksa sekaligus menjadi Ummi, Kak Fatimah, Kak Zahra, dan Kak Aisyah. Abi harus mengurusi pernak pernik kebutuhan Delisa dan dirinya sendiri. Dan salah satunya yang meskipun sepele namun mendesak tentu urusan masak-memasak tadi.

Delisa sebenarnya tumbuh lebih dewasa dua bulan terakhir. Delisa jauh lebih bertanggung-jawab. la membantu Abi menyapu rumah. Mencuci piring. Bahkan sudah bisa mencuci pakaian dan belajar menyetrika. Delisa juga tidak banyak berseru meminta tolong. Dengan sendirinya pengertian itu datang kepadanya (Liye, 2008:177).

Kutipan di atas mengandung aspek tanggung jawab yang ditunjukkan oleh Abi Usman sebagai ayah. la bertanggung jawab mengurus anaknya dengan peran ganda yaitu sebagai ayah sekaligus ibu bagi Delisa karena isteri dari Abi Usman telah meninggal. Kutipan di atas lebih tepatnya dikategorikan sebagai aspek moral tanggung jawab hubungannya dengan keluarga. Sedangkan aspek moral tanggung jawab dari tokoh Delisa tampak dari perbuatan yang dilakukan Delisa yaitu membantu pekerjaan orang tua atau meringankan pekerjaan orang tua. Perbuatan Delisa dalam kutipan di atas dapat digolongkan sebagai aspek moral tanggung jawab hubungannya dengan orang tua

\section{4) Kemandirian}

Kemandirian mengajarkan kita untuk tidak selalu bergantung pada orang lain. Aspek moral kemandirian dalam novel Hafalan Shalat Delisa karya Tere Liye dapat dilihat dari kutipan berikut.

Bukan itu! Delisa bukan tidak lapar. Tetapi masakannya! Sudah seminggu terakhir Abi mencoba memasak sendiri. Tidak tergantung lagi dengan makanan di dapur umum. "Tidak selamanya dapur umum ada, Delisa" itu penjelasan Abi saat dia memutuskan untuk mulai memasak sendiri di rumah. Dan selama tujuh hari terakhir ini, sayangnya masakan Abi ternyata jauh dari enak. Hambar. Tak berbentuk pula (Liye, 2008:176).

Kutipan di atas menjelaskan aspek moral kemandirian yang ditunjukkan oleh Abi Usman. Sebelumnya, Abi Usman dalam urusan makan selalu mengandalkan dapur umum. Semenjak Abi memutuskan pulang ke rumah, Abi Usman belajar memasak sendiri. Abi Usman dalam kutipan di atas dijelaskan tidak lagi bergantung kepada orang lain, ia mau berusaha mandiri dalam setiap hal seperti memasak.

Delisa sebenarnya tumbuh lebih dewasa dua bulan terakhir. Delisa jauh lebih bertanggung-jawab. la membantu Abi menyapu rumah. Mencuci piring. Bahkan sudah bisa mencuci pakaian dan belajar menyetrika. Delisa juga tidak banyak berseru minta tolong. Dengan sendirinya pengertian itu datang kepadanya. Delisa selalu mengerjakan sendiri apa yang bisa ia kerjakan, Termasuk urusan menyiapkan pakaian mengajinya (Liye, 2008:177).

Kutipan di atas menggambarkan aspek kemandirian Delisa. Perbuatan yang dilakukan oleh Delisa merupakan cerminan perbuatan mandiri. Meski Delisa masih anak-anak, ia mampu mengerjakan pekerjaan orang dewasa seperti 
Rita Nilawijaya, Awalludin

Tinjauan Sosiologi Sastra dalam Novel Hafalan Shalat Delisa Karya Tere Liye dan Relevansinya terhadap Pembelajaran Sastra di SMA

mencuci piring, mencuci pakaian, menyapu rumah, dan belajar menyetrika. Delisa mulai mandiri seiring pertumbuhannya dan berusaha melakukan perbuatanperbuatan tersebut dengan sebaik-baiknya tanpa mengeluh minta tolong kepada orang lain

\section{5) Realistik dan Kritis}

Sifat realistis dan kritis dapat mengajarkan kita untuk mempertimbangkan segala sesuatu yang dihadapi untuk mencapai kebaikan baik bagi diri sendiri maupun bagi orang lain. Adapun aspek moral realistik dan kritis dalam novel ini dapat dilihat pada kutipan berikut.

\footnotetext{
"In-na sha-la-ti, wa-nu-su-ki, wa-ma.... wa-ma.... wa-ma-ma-ti... Wa-mah-ya-ya..."

"Yee... salah. Kebalik, tuh!" Aisyah nyengir; mendapatkan bahan baru menggoda adiknya.

Bacaan doa iftitah Delisa memang tertukar urutannya. Zahra menepuk lengan Aisyah.

"Giliran Aisyah sekarang!" Aisyah buru-buru melanjutkan permainan.

Delisa juga buru-buru melihat buku bacaan shalat di tangannya. Eh iya, bacaannya kebalik.

Delisa nyengir menggemaskan.

"Kan nggak mungkin mati dulu, baru yaya... Makanya Delisa kalau menghafal ingat artinya!

Jangan Cuma dihafal." Aisyah sok-dewasa, sok-paham menasihati.

Bagaimana pula adiknya akan tahu teknik menghafal seperti itu? Mati berarti mati; yaya berarti hidup. Delisa mana tahu artinya. Delis abaca Arab-nya saja ribet minta ampun belum bisa; baru belajar.

Tetapi Delisa diam saja diolok seperti itu. Delisa justru sedang berpikir sendiri. Memikirkan olok-olok Kak Aisyah barusan. Ya benar. Kak Aisyah benar... di mana-mana mati pasti terakhir, kan? Jadi dia setelah wamah-yaya.... Baru wama-mati.

Menutup lagi buku hafalan shalatnya.

"In-na sha-la-ti, wa-nu-su-ki, wa-ma.... wa-ma.... wa-mah-ya-ya.... Wa-ma-ma-ti..."

Hore! lancar. Delisa nyengir senang.

"Makasih ya, Kak!" Delisa berseru kepada kakaknya.

Giliran Aisyah yang bingung! Terima kasih apanya? (Liye, 2008:13-14).
}

Kutipan di atas menggambarkan aspek moral realistis dan kritis yang ditunjukkan oleh tokoh Delisa. Penggambaran sikap realistis tokoh Delisa yaitu dapat menerima kenyataan bahwa bacaan salatnya terbalik. Selanjutnya, penggambaran sikap kritis yang ditunjukkan oleh tokoh Delisa yaitu mau menerima masukan yang diberikan oleh kakaknya dan merenungkan kesalahan tersebut. Setelah merenungkan kesalahan tersebut, Delisa menemukan solusi yang tepat dan ia dapat menghafalkan bacaan salatnya dengan lancar.

\section{c. Relevansinya terhadap Pembelajaran Sastra di SMA}

Relevansi hasil penelitian dari novel Hafalan Shalat Delisa karya Tere Liye didasarkan pada pembelajaran kelas XI semester 1 sesuai Kurikulum Tingkat Satuan Pendidikan (KTSP) SK 7. Memahami berbagai hikayat, novel Indonesia/ novel terjemahan, dan KD 7.2. Menganalisis unsur-unsur intrinsik dan ekstrinsik novel Indonesia/ novel terjemahan. Kemudian, bisa juga diterapkan dalam pembelajaran novel pada kurikulum 2013 pada jenjang SMA. Jenis bahan ajar

Silampari Bisa: Jurnal Penelitian Pendidikan Bahasa Indonesia, Daerah, dan Asing Vol. 4, No. 1, June 2021 
Rita Nilawijaya, Awalludin

Tinjauan Sosiologi Sastra dalam Novel Hafalan Shalat Delisa Karya Tere Liye dan Relevansinya terhadap Pembelajaran Sastra di SMA

sastra yang diimplementasikan sebagai hasil dari penelitian berupa bahan ajar cetak yaitu bagian dari LKS tentang nilai moral dalam novel Hafalan Shalat Delisa karya Tere Liye.

\section{Pembahasan}

Novel Hafalan Shalat Delisa karya Tere Liye menunjukkan bentuk-bentuk perilaku bermoral di tengah cobaan hidup yang ditunjukkan melalui tokoh-tokoh dalam cerita. Moral dalam novel Hafalan Shalat Delisa tidak lain merupakan bagian dari amanat yang hendak disampaikan oleh Tere Liye kepada pembaca dengan tujuan agar dalam kondisi dan situasi apapun kita harus senantiasa berbuat kebaikan. Hal ini terlihat dalam tema novel Hafalan Shalat Delisa karya Tere Liye yakni tentang perilaku pantang menyerah, sabar, dan tabah dalam menjalani kehidupan. Hal ini juga sesuai hasil penelitian Zulaicha (2009) serta Wanispa \& Hidajati (2019), bahwa dalam novel Shalat Delisa karya Tere Liye terdapat nilai-nilai pendidikan akhlak dan nilai pendidikan karakter dalam setiap peristiwa yang dihadirkan oleh tokoh utama.

Tema dalam novel tersebut ditunjukkan oleh tokoh utama dalam cerita bernama Delisa. Begitu juga alur yang digunakan dalam novel Hafalan Shalat Delisa karya Tere Liye yaitu alur maju/progressive. Aspek Moral dalam Novel Hafalan Shalat Delisa karya Tere Liye diklasifikasikan menjadi 5 macam yaitu:

1. Kejujuran

Aspek moral kejujuran yang terdapat dalam kutipan di atas terbukti pada perkataan dari Delisa yaitu cinta Abi karena Allah Swt. Perkataan tersebut tulus dari seorang Delisa yang masih berusia anak-anak. Kata-kata yang keluar dari Delisa yang masih polos merupakan kata-kata yang tulus dari hatinya.

2 Nilai-Nilai Otentik

Dalam novel ini yaitu memegang teguh pendiriannya. Kebaikan yang diberikan oleh Koh Acan tersebut tidak dibuat-buat dalam arti tulus dari pribadinya dan bukan hanya mencari simpati semata. Keaslian dari seorang Koh Acan yaitu sebagai bentuk apresiasi Koh Acan terhadap anak-anak yang mau belajar beribadah dengan sungguh-sungguh.

3. Tanggung Jawab

Tokoh Abi Usman sebagai ayah, ia bertanggung jawab mengurus anaknya dengan peran ganda yaitu sebagai ayah sekaligus ibu bagi Delisa karena isteri dari Abi Usman telah meninggal. Kutipan di atas lebih tepatnya dikategorikan sebagai aspek moral tanggung jawab hubungannya dengan keluarga. Sedangkan aspek moral tanggung jawab dari tokoh Delisa tampak dari perbuatan yang dilakukan Delisa yaitu membantu pekerjaan orang tua atau meringankan pekerjaan orang tua.

4 Kemandirian

Perbuatan yang dilakukan oleh Delisa merupakan cerminan dari perbuatan mandiri. Meski Delisa masih anak-anak, ia mampu mengerjakan mengerjakan pekerjaan orang dewasa seperti mencuci piring, mencuci pakaian, menyapu rumah, dan belajar menyetlika. Delisa mulai mandiri seiring pertumbuhannya. la berusaha melakukan perbuatan-perbuatan tersebut dengan sebaik mungkin tanpa mengeluh minta tolong kepada orang lain 
Rita Nilawijaya, Awalludin

Tinjauan Sosiologi Sastra dalam Novel Hafalan Shalat Delisa Karya Tere Liye dan Relevansinya terhadap Pembelajaran Sastra di SMA

\section{Realistik dan Kritis}

Penggambaran sikap realistis dari tokoh Delisa yaitu dapat menerima kenyataan bahwa bacaan salatnya terbalik. Sedangkan penggambaran sikap kritis yang ditunjukkan oleh tokoh Delisa yaitu mau menerima masukan yang diberikan oleh kakaknya dan merenungkan kesalahan tersebut. Setelah merenungkan kesalahan tersebut akhirnya Delisa menemukan solusi yang tepat dan ia dapat menghafalkan bacaan shalat tersebut dengan lancar.

Novel Hafalan Shalat Delisa karya Tere Liye, sesuai dengan fakta cerita di dalam novel tersebut, menimbulkan dampak positif bagi kehidupan. Oleh sebab itu, kajian sosiologi sastra dalam novel ini sangat relevan dengan pembelajaran sastra di kelas XI semester I (ganjil), standar kompetensi (7) memahami berbagai hikayat, novel Indonesia/novel terjemahan dan kompetensi dasar (7.2) menganalisis unsur-unsur intrinsik dan ekstrinsik novel Indonesia/novel terjemahan dalam Kurikulum Tingkat Satuan Pendidikan (KTSP). Kemudian, relevan juga diterapkan sebagai materi ajar, khususnya pembelajaran novel di SMA pada kurikulum 2013.

\section{Simpulan}

Berdasarkan hasil analisis dan pembahasan yang dilakukan terhadap novel Hafalan Shalat Delisa karya Tere Liye, dapat disimpulkan hasil penelitian sebagai berikut. Analisis sosiologi sastra dalam novel Hafalan Shalat Delisa karya Tere Liye memuat tema dan fakta cerita (alur, penokohan, dan latar/ setting) yang diceritakan dalam novel, meliputi: a) temanya adalah sikap pantang menyerah, kerja keras, dan sabar b) alur yang digunakan adalah alur maju, c) tokoh yang terdapat dalam novel antara lain: Delisa sebagai tokoh utama sedangkan tokoh tambahan meliputi Ummi, Kak Fatimah, Kak Aisyah, Kak Zahra, Abi Usman, Ustadz Rahman, Ibu guru Nur, Koh Acan, Tiur, Umam, Sersan Ahmed, Prajurit Smith/ Salam, Suster Shopi, dan Kak Ubai, d) latar/setting antara lain: latar tempat di kota Lhok Nga Aceh, Kapal induk dan rumah sakit. Latar waktu terjadi pada 25 Desember 2004 hingga 21 Mei 2005. Latar sosial dalam novel menceritakan kebiasaan hidup, tradisi, dan keyakinan dalam beragama.

Aspek moral dalam novel Hafalan Shalat Delisa karya Tere Liye meliputi moral kejujuran yang berkaitan dengan perilaku jujur dan tidak jujur yang ditunjukkan oleh tokoh Delisa, nilai-nilai otentik yang ditunjukkan oleh Koh Acan yang memiliki pendirian yang kuat. Moral tanggung jawab meliputi perbuatan tanggung jawab oleh tokoh Delisa dan Abi Usman dan perbuatan tidak bertanggung jawab dari tokoh Delisa. Moral kemandirian ditunjukkan oleh tokoh Delisa dan Abi Usman. Selanjutnya, moral realistik dan kritis ditunjukkan oleh tokoh Delisa. Kemudian, hasil kajian sosiologi sastra dalam novel Hafalan Shalat Delisa karya Tere Liye relevan terhadap pembelajaran sastra di kelas XI semester I Sekolah Menengah Atas dengan mengacu pada standar kompetensi (7) memahami berbagai hikayat, novel Indonesia/novel terjemahan dan kompetensi dasar (7.2) menganalisis unsur-unsur intrinsik dan ekstrinsik novel Indonesia/novel terjemahan dalam Kurikulum Tingkat Satuan Pendidikan. Selain itu, relevan juga diberikan pada pembelajaran novel di SMA pada kurikulum 2013. 
Rita Nilawijaya, Awalludin

Tinjauan Sosiologi Sastra dalam Novel Hafalan Shalat Delisa Karya Tere Liye dan Relevansinya terhadap

Pembelajaran Sastra di SMA

\section{Daftar Pustaka}

Awalludin, A., \& Anam, S. (2019). Stratifikasi sosial dalam novel Pabrik karya Putu Wijaya. Silampari Bisa: Jurnal Penelitian Pendidikan Bahasa Indonesia, Daerah, dan Asing, 2(1), 15-28. doi:10.31540/silamparibisa.v2i1.276

Liliweri, A. (2014). Pengantar studi kebudayaan. Bandung: Nusa Media.

Liye, T. (2008). Hafalan shalat delisa. Jakarta: Republika.

Nilawijaya, R., \& Inawati, I. (2020). Resepsi mahasiswa Universitas Baturaja terhadap nilai moral tokoh utama dalam novel Ayat-Ayat Cinta karya Habiburrahman El Shirazy. Lentera: Jurnal IImiah Kependidikan, 13(1), 63-78. http://jurnal.stkippgribl.ac.id/index.php/lentera/article/view/504

Nilawijaya, R., \& Inawati, I. (2020). Tinjauan sosiologi sastra novel Ayah karya Andrea Hirata dan implementasinya sebagai bahan ajar sastra di SMA. Jurnal IImiah Bina Bahasa, 13(02), 23-32. https://doi.org/10.33557/binabahasa.v13i02.1173

Noermanzah, N. (2017). Plot in a collection of short stories "Sakinah Bersamamu" works of Asma Nadia with feminimism analysis. Humanus, 16(1), 27-28. doi:10.24036/jh.v16i1.7015

Nurgiyantoro, B. (2013). Teori pengkajian fiksi. Yogyakarta: Gajah Mada University Press.

Pradopo, R.D. (2008). Beberapa teori sastra: Metode kritik dan penerapannya. Yogyakarta: Pustaka Pelajar.

Prastica, D., \& Wulandari, Y. (2020). Diksi dan gaya kalimat dalam novel Hafalan Shalat Delisa karya Tere Liye. Pena Literasi, 2(2), 64. doi:10.24853/pl.2.2.220-225

Ratna, N.K. (2010). Paradigma sosiologi sastra. Yogyakarta: Pustaka Pelajar.

Satinem, S., Juwati, J., \& Noermanzah, N. (2020). Developing teaching material of poetry appreciation based on students competency analysis. English Review: Journal of English Education, 8(2), 237. doi:10.25134/erjee.v8i2.2707

Soeparwoto, dkk. (2004). Psikologi perkembangan. Semarang: Unnes Press.

Sufanti, M. (2010). Strategi pengajaran bahasa dan sastra Indonesia. Surakarta: Yuma Pustaka. 
Rita Nilawijaya, Awalludin

Tinjauan Sosiologi Sastra dalam Novel Hafalan Shalat Delisa Karya Tere Liye dan Relevansinya terhadap Pembelajaran Sastra di SMA

Sukma, E., \& Hafrison, M. (2020). Nilai-Nilai moral dalam novel Ayahku Bukan Pembohong karya Tere Liye dan implikasinya terhadap pembelajaran teks novel di SMA. Pendidikan Bahasa Indonesia, 9(3), 48. doi:10.24036/110718-019883

Sulaeman, A., Goziyah, Purawinangun, I.A., Noermanzah. (2020). Social value in the novel Hatta: Aku Datang karena Sejarah by Sergius Sutanto as teaching materials in teaching literature in schools. International Journal of Scientific and Technology Research, 9(3). 611. http://www.ijstr.org/paper-references.php?ref=|JSTR-0320-32332

Wanispa, E., \& Hidajati, E. (2019). Nilai pendidikan berkarakter dalam novel Hafalan Sholat Delisa karya Tere Liye: Kajian sosiologi sastra. Jurnal IImiah Bina Edukasi, 11(01), 13-25. doi:10.33557/jedukasi.v11i01.202

Zulaicha, S. (2009). Nilai-nilai pendidikan akhlak pada novel Hafalan Shalat Delisa karya Tere Liye. MUDARRISA: Journal of Islamic Education, 1(1), 13. doi:10.18326/mdr.v1i1.13-46 